\title{
セルロースの燃焼 (2)
}

\section{6. 七ルロース物質の着火（Ignition）}

セルロース物質の燃焼に先だつ着火現象に関しては， 従来, 防炎面の基礎研究として，D. L. Simms ${ }^{20)}$ をはじ め数人の研究者によって継続的に研究がなされている. 我国においては，秋田一雄 ${ }^{31}$,21) の精力的な研究が著名で ある・

セルロース物質の Ignition（着火）は，その機構によ って次の 3 つに大別される.

Spontaneous-Ignition（発火）……高温領域に执いて 物質が加熱を受けた時, 自から発火する場合・

Piloted-Ignition, Kindled-Ignition（引以）…...高 温領域において，口火にもとついて起る発火在言う.

Self-Ignition（自然発火）……低温領域で，内部発熱 の蓄積にもとづいて起とる発火.

セルロース系の廃竬物の処理において, 焼却処理とし て直接的に関連するものは, Spontaneous Ignition（発 火）あしくは, Piloted Ignition (引火) である. 低温 領域の Self-Ignition（自然発火）は，火苂の原因の 1 つとして重要なものであるが，廃椠物の焼却処理には直 接的には関連はない。むしろ, 廃棄物の理立や堆積時の 発火防止の面で興味ある現象といえる.

さて，一般にセルロース物質の代表である木材など は, $500^{\circ} \mathrm{C}$ 前後に加熱されると発火することは，古くか

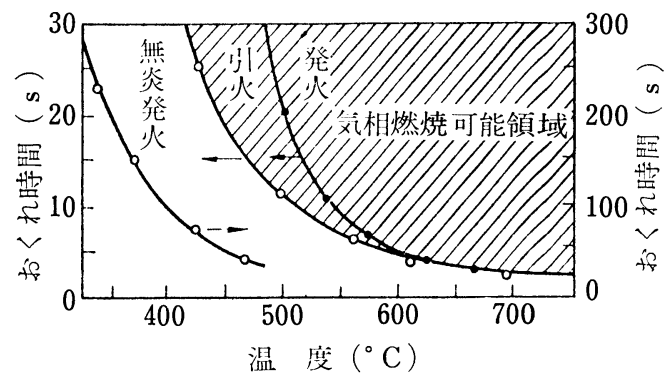

図-10 木材の着火形式

* 日立造船(㑣)第 4 研究室

** 京都大学工学部衛生工学教室

$\begin{array}{lll}\text { 春 } & \text { 山 } & \text { 鴻* } \\ \text { 高 } & \text { 月 } & \text { 紘** }\end{array}$

ら経験的に知られているとてろである。しかしながら， この着火現象も詳細に見ると，物質の性状（形状や物 性), 加熱状態によって, 着火に要する時間は著しく異 なっている(図-10参照).

本章では現在までに，セルロース物質の着火につい て, 種々の研究者によって明らかにされたてとがらを, 秋田一雄の 研究報告を中心に, 整理してみようと考え る.

\section{6-1 発火 (Spontaneous Ignition)}

まず, Spontaneous Ignition については, 各研究者 の間で，Spontaneous Ignition の支配因子は，表面温 度であるという見方が現在，大勢を占めている．古く は, Bamford ${ }^{22)}$ らの研究において, 木材なよ゙のセルロー ス物質の Spontaneous Ignitionは，加熱さ机たとき表 面から発生する熱分解ガスの発生量に支配されるという 考え方を導いていたが，現在では，種々の実験と理論解 析から，Spontaneous Ignition は，対象であるセルロ 一ス物質の形状にはあまり関係なく，その表面温度があ る一定温度に達したときに生ずることが明らかになって きた。これらのセルロース物質の着火機構の研究は, ほ とんどがその研究方法は類似している.すなわち，対象

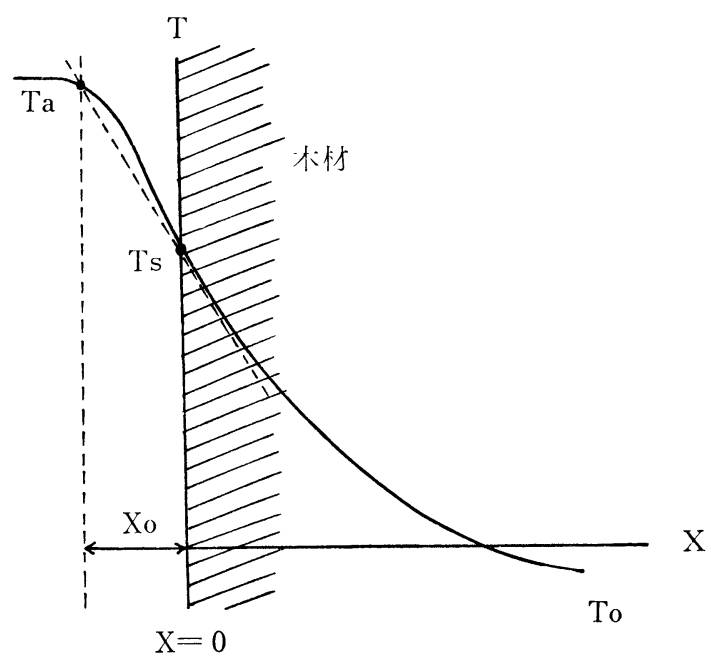

図-11 木材の表面近くの温度分布のモデル ${ }^{3)}$ 
セルロース物質（多くは木材について）を平板もしくは 半無限の固体とみなし，乙れに固体内の热伝導方程式を 仮定し, さらに実験を行なって, その固体内温度測定值 と比較して, 種々の知見を得る方法である. 秋田 ${ }^{3)}$ は, この熱伝導方程式に最む単純な形を仮定した.

すなわち，ある温度雾囲気下におかれた木材の内部の 温度分布は，図-11 に示すような半無限固体の付加厚を 仮定したモデルをむとに

$$
\begin{aligned}
& \frac{\partial \mathrm{T}}{\partial \mathrm{t}}=\kappa{ }^{\partial^{2} \mathrm{~T}} \\
& \partial \mathrm{x}^{2} \\
& \mathrm{t}=0 \quad \mathrm{~T}=\mathrm{T}_{0} \quad \text { (初期温度) } \\
& \mathrm{x}=-\mathrm{x}_{0} \mathrm{~T}=\mathrm{T}_{\mathrm{a}} \quad \text { (雲囲気温度) } \\
& -\left(\begin{array}{l}
\partial \mathrm{T} \\
\partial \mathrm{x}^{-}
\end{array}\right)_{\mathrm{s}}=\mathrm{h}\left(\mathrm{T}_{\mathrm{s}}-\mathrm{T}_{\mathrm{a}}\right) \quad \mathrm{h}=\alpha / \mathrm{K}
\end{aligned}
$$

とこに

$\mathrm{T}:$ 温度, $\mathrm{t}$ : 時間, $\mathrm{x}$ : 位置座標

$\boldsymbol{\kappa}:$ 熱拡散率, $\mathrm{h}:$ 相対熱伝達係数

$\alpha:$ 熱伝達係数, $\mathrm{K}:$ 熱伝導率

$\mathrm{x}_{0}:$ 付加厚 $($ 仮想厚 $)=\frac{1}{\mathrm{~h}}$

解

$$
\mathrm{T}=\mathrm{T}_{0}+\left(\mathrm{T}_{\mathrm{a}}-\mathrm{T}_{\mathbf{0}}\right)\left\{1-\operatorname{erf}\left(\frac{\mathrm{x}+\mathrm{x}_{\mathbf{0}}}{2 \sqrt{\kappa \mathrm{t}}}\right)\right\}(6-4)
$$

この解と試料内の温度測定の㬰測值は比較的よく一致し た。また，ての式をもとに実測值から発火洔の表面温度 を逆算して $495^{\circ} \mathrm{C} と い う$ 值を Spontaneous Ignitionの表 面温度としている.

また，ある一定の熱輻射を受けた場合も，基礎方程式 は同じく，境界条件を

$$
\left[\mathrm{K} \frac{\partial \mathrm{T}}{\partial \mathrm{x}^{-}}+\mathrm{I}-\boldsymbol{\alpha}\left(\mathrm{T}-\mathrm{T}_{\mathrm{a}}\right)\right]_{\mathrm{x}=0}=0
$$

初期条件を

$$
\mathrm{t}=0 \quad \mathrm{~T}=\mathrm{T}_{\mathrm{a}}=\mathrm{T}_{0}
$$

として

解

$$
\begin{gathered}
\mathrm{T}-\mathrm{T}_{0}=\underset{\mathrm{I}}{\alpha}\left[1-\operatorname{erf}\left(\begin{array}{c}
\mathrm{x} \\
2 \sqrt{\kappa \mathrm{t}}
\end{array}\right)-\exp \left(\begin{array}{l}
\alpha \\
\mathrm{K}
\end{array} \cdot \mathrm{x}+\frac{\alpha^{2}}{\mathrm{~K}^{2}} \cdot \kappa \mathrm{t}\right)\right. \\
\left\{1-\operatorname{erf}\left(\underset{2 \sqrt{\kappa \mathrm{t}}}{\mathrm{x}}+\frac{\alpha}{\mathrm{K}} \cdot \sqrt{\kappa \mathrm{t}}\right\}\right]
\end{gathered}
$$

表面温度

$$
\begin{aligned}
& \mathrm{T}_{\mathrm{s}}=\mathrm{T}_{0}+\frac{\mathrm{I}}{\alpha}\left\{1-\exp \left(\beta^{2}\right) \cdot(1-\operatorname{erf}(\beta))\right\} \\
& \beta=\left(\begin{array}{l}
\alpha \\
\mathrm{K}
\end{array}\right) \sqrt{\kappa \mathrm{t}}=\mathrm{h} \sqrt{\kappa \mathrm{t}}
\end{aligned}
$$

ここに, $I=$ 輻射強度

この式と実測值とから, 輻射加熱による発火時の木材の
表面温度は, $I=15 \mathrm{cal} / \mathrm{cm}^{2} \cdot \mathrm{sec}$ で種々の木材の平均とし て $498^{\circ} \mathrm{C}$ とう值を算出している.

一方, $\mathrm{Simms}^{23)}$,24) も同様な熱伝導方程式汃ら輻射を受 けた木材が Spontaneous Ignition する時の表面温度 は, 輻射強度が $1 \sim 14 \mathrm{cal} / \mathrm{cm}^{2} \cdot \mathrm{sec}$ の範囲で $525^{\circ} \mathrm{C}$ とい う值を道いている.

しかし, Martin ${ }^{14,25)}$ は, 輻射強度が $5 \sim 20 \mathrm{cal} / \mathrm{cm}^{2}$ ・ sec の範囲で， $\alpha$-cellulose の平板の Spontaneous Ignition の表面温度を直接, 赤外線光高温計 (Infrared Pyrometer）を用いて测定しているが，乙の測定值では 表面温度は600〜 $650^{\circ} \mathrm{C}$ であと報告している．乙れは， また，W. D. Weatherford ${ }^{26)}$ らの数值計算によっても 支持されている.

このように研究者によって，セルロース物質の Spontaneous Ignition 時の表面温度が異なるのは, 数值解 析の諸パラメーターへの採用した物性值の差異や実験条 件の差異なども考えられるが， $\mathrm{Simms}^{23)}$ によれば，輻 射加熱の場合, この差異は各研究者の実験で受熱面積が 異なるためと説明している。

一方, Andersen ${ }^{27)}$ は, 試料片への受熱された輻射工 ネルギー量によって, 発火表面温度が異なるとして, 計 算から図-12に示すような結果を示している.

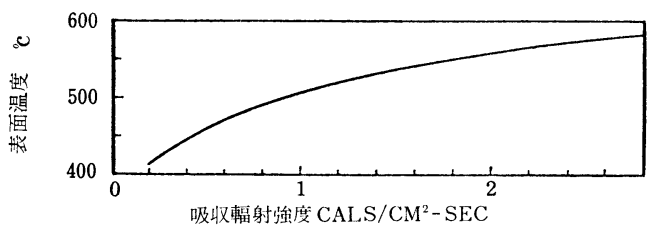

図-12 輻射強度と発火表面温度との関係 (計算值) ${ }^{27}$

いずれにしても，木材などのセルロース物質の Spontaneous Ignition に関しては，加熱方法が決まればそ の他に発火エネルギーを与えるものがないので，その物 体の形状や内部温度にあまり関係なく，その表面がある 一定温度に達した時に発火すると言えよう。秋田 ${ }^{3)}$ は, この温度は，とりもなおさず加熱によって発生する分解 ガスの可然性混合気の発火温度であろうと説明してい る.

また，物質の発火性と密度との関係は，加熱エネルギ 一が一定の場合, 密度が小さいものほど热伝導率が小さ くなり, 表面温度の上昇に好都合となり, 発火しやすい ことも認められている.

\section{6-2 引火 (Piloted Ignition)}

Piloted Ignition の場合, 着火エネルギーとして, 物 質表面温度より高い口火（火炎もしくは，放電火花）が あるので，物質の着火の条件は表面近くに放出される熱 分解ガスの量と質に強く依存している. 屯ちろん, 口火 
(pilot flame) の位置や空気 (特に酸素) との混合状態 によっても, Piloted Ignition は大きく左右される.

したがって，一般に引火温度を定めることはできな い. 極端に言えば，七ルロース物質の熱分解温度以上で 分解ガスの逸散を少なくして長時間おけば，どの温度で も，いずれは着火することになる。

しかしながら，同条件下で加熱を行なう場合，口火は あるときとないときでは，口火のある方が早く着火する ことは事実である。

$\mathrm{Simms}^{28)}$ は，木片を $0.25 \sim 1.50 \mathrm{cal} \cdot \mathrm{cm}^{-2} \cdot \mathrm{s}^{-1}$ の範囲 で，ガスの炎による輻射加熱を行ない， pilot flame を 木片表面より図-13，図-14のような位置に設定した場合 の Pilot Ignition の状沇在研究している.

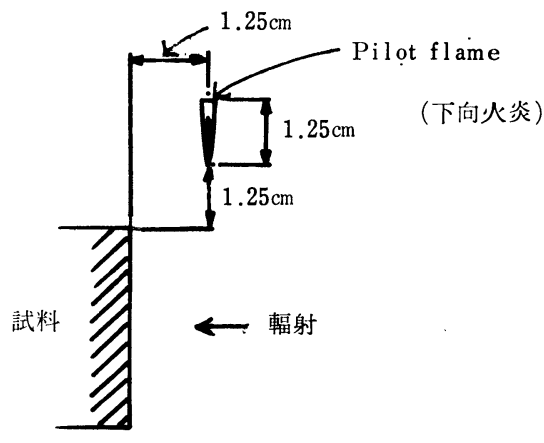

図-13 Pilot Ignition の実験 Case $(1)^{281}$

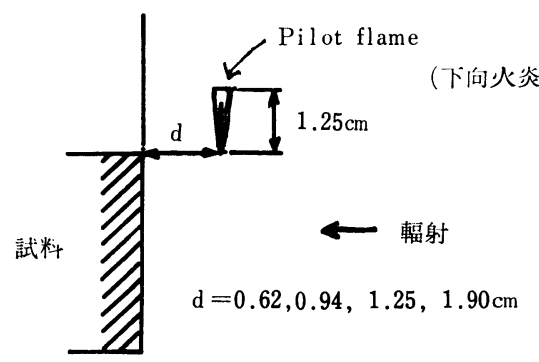

図-14 Pilot Ignition の実験 Case $(2)^{28)}$

これらの実験結果を先に示した（6-8）式すなわち,

$$
\mathrm{T}_{\mathrm{s}}-\mathrm{T}_{0}=\frac{\mathrm{I}}{\alpha}\left(1-\mathrm{e}^{\xi 2} \operatorname{erf} \beta\right)
$$

に対応させて, Pilot Ignition の表面温度を求めてみる と，木片の種類によって若干の相違はあるが, case（1）

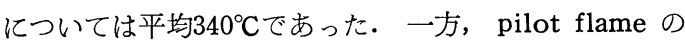
位置が異なる case (2) では, $\theta_{\mathrm{F}}=\mathrm{T}_{\mathrm{s}}-\mathrm{T}_{0}$ は，

$$
\begin{aligned}
& \mathrm{d}=0.62 \mathrm{~cm} \text { で } \theta_{\mathrm{F}}=300^{\circ} \mathrm{C} \\
& \mathrm{d}=1.25 \mathrm{~cm} \text { で } \theta_{\mathrm{F}}=380^{\circ} \mathrm{C} \\
& \mathrm{d}=1.90 \mathrm{~cm} \text { で } \theta_{\mathrm{F}}=410^{\circ} \mathrm{C}
\end{aligned}
$$

と表面から pilot flame が離れるにつれて Pilot Ignition 時の表面温度は，高くなる結果となっている。
また，W. D. Weatherford ${ }^{26)}$ らの Pilot Ignition の 実験結果でも, 表面温度は $350^{\circ} \mathrm{C}$ とう值を得ている. なお，Simmsによれば，木材の小片に対し Pilot Ignitionを起こす輻射強度の最小の值は， $0.31 \mathrm{cal} ・$ $\mathrm{cm}^{-2} \cdot \mathrm{sec}^{-1}$ であり, Spontaneous Ignition の最小輻射 強度は, $0.74 \mathrm{cal} \cdot \mathrm{cm}^{-2} \cdot \mathrm{sec}^{-1}$ である。

以上, 引以や発火に関し, 表面温度に焦点を合せてき たが，実際にセルロース物質の表面で発火するものは， セルロース物質の熱分解ガスである．との分解ガスにつ いては，すでに 4 章でのべたが，着火に関与する分解ガ スは，水素や一酸化炭素などの初期の分解ガスよりはむ しろ，アルデヒド，ケトン，エステルなどの炭化水素が 重要な役割をはたし，着火時はそれらのガスの理論比よ り低い濃度で発火するといわれている。

\section{6-3＼cjkstart水分がセルロースの着火に及ぼす影響}

セルロース系の廃棄物の焼却処理においては, 対象物 が水分を多く含んでいる場合が多い. したがって, 着火 に及ぼす水分の影響を見ることも興味のある事柄であ る.

そこで筆者等は, 粉佃したろ紙(JIS 9mesh, 径 $2.0 \mathrm{~mm}$ の篩を通したもの）を対象に水分を０\%，20\%，40\%， $60 \%$ と变化させ，石英カゴ（肉厚 $2.0, \phi 30 \times 20 ）$ 亿入 れ, 等囲気温度を $400^{\circ} \mathrm{C}, 500^{\circ} \mathrm{C}, 600^{\circ} \mathrm{C}, 700^{\circ} \mathrm{C}$ 亿設定し た電気炉に捜入し，発火までの時間を测定した。この実 験装置の概略は図-15に示す. その結果は表- 9 亿示すと おりであるが，高温域 $\left(600^{\circ} \mathrm{C} \sim 900^{\circ} \mathrm{C}\right)$ では水分が 0 〜 $20 \%$ 程度の場合, 発火の時間遅れは, ほとんどみとめら れない. しかし，水分が40\%を超えると，明らかに水分

\begin{tabular}{|c|c|c|c|c|c|c|}
\hline \multirow{3}{*}{ 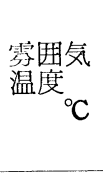 } & \multirow{3}{*}{$\begin{array}{l}\text { みかけ } \\
\text { 密度 } \\
\mathrm{g} / \mathrm{cm}^{3}\end{array}$} & \multirow{3}{*}{$\begin{array}{l}\text { 水分 } \\
0 \%\end{array}$} & \multirow{3}{*}{$\begin{array}{l}\text { 水分 } \\
20 \%\end{array}$} & \multirow{3}{*}{$\begin{array}{l}\text { 水分 } \\
40 \%\end{array}$} & 水分 & $60 \%$ \\
\hline & & & & & \multicolumn{2}{|c|}{ みかけ密度 } \\
\hline & & & & & $\begin{array}{l}0.047 \\
\mathrm{~g} / \mathrm{cm}^{3}\end{array}$ & $\begin{array}{l}0.094 \\
\mathrm{~g} / \mathrm{cm}^{3}\end{array}$ \\
\hline 400 & 0.047 & & $\begin{array}{l}\text { 着火 } \\
\text { せず }\end{array}$ & $\begin{array}{l}\text { 着火 } \\
\text { せず }\end{array}$ & \begin{tabular}{|l|} 
着火 \\
せず
\end{tabular} & \\
\hline 450 & 0.047 & 99 & & & & \\
\hline 500 & 0.047 & 31 & 63 & 73 & 102 & 139 \\
\hline \multirow{2}{*}{600} & 0.047 & 7.0 & 25 & & 65 & \\
\hline & 0.094 & 13.5 & 16.5 & 42 & & 88 \\
\hline 700 & 0.047 & 1.0 & 5.0 & 15 & 35 & 54 \\
\hline 900 & 0.047 & $<1.0$ & $<1.0$ & 10.0 & 21.5 & \\
\hline
\end{tabular}
による発火遅れの影響が現われる，また，密度の影響

表-9 水分を含んだ粉末ろ紙の着火時間

(単位 sec)

含水率 : Wet 基準 


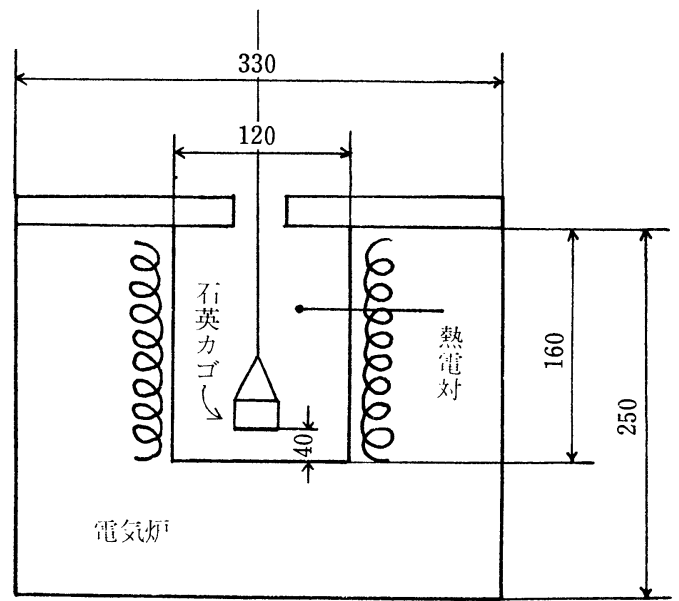

図-15 セルロース物質の発火実験装置

は，水分が60\%の場合および雾囲気温度が $600^{\circ} \mathrm{C}$ の場合 について, 各々, 倍の密度のものを使用したが, この密 度の範囲では，その影響は顕著であった。

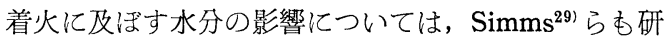
究を行なっている. 彼の木片を対象にした実験において あ Pilot Ignition の場合，水分の影響が顕著に現われ るのは，水分が $40 \%$ 以上の場合である. そして水分が 60 \%になると, 引火に必要な輻射強度 (radiation intensity）は，乾燥したものに比して倍の值を示すと報告し ている（図-16，図17参照).

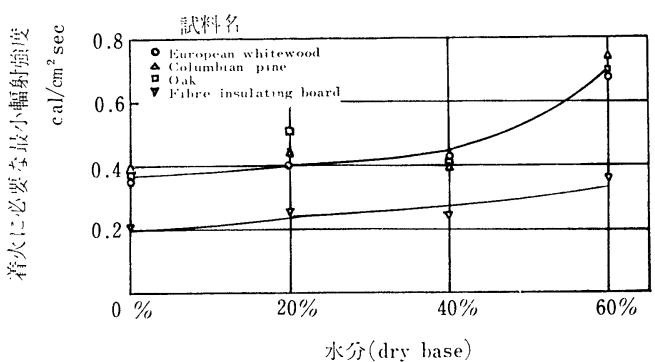

図-16 引火（Pilot Ignition）に必要な最小輻射強度之 水分との関係 ${ }^{29)}$ (試料 $7.6 \mathrm{~cm}$ 角)

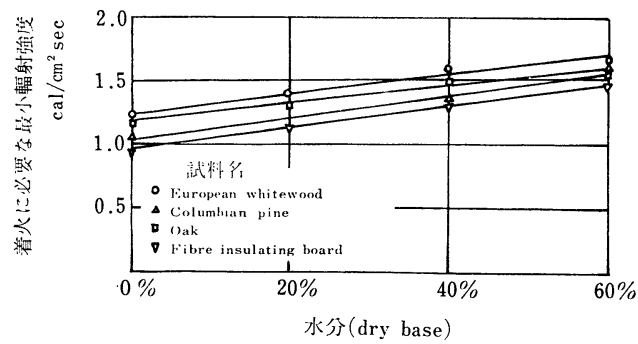

図-17 発火（Spontaneous Ignition）に必要な最小輻 射強度と水分との関係 ${ }^{29)}$ （試料 $7.6 \mathrm{~cm}$ 角）
水分が着火させようとする物質に含まれる場合，

（1）水の蒸発により高温部を冷し，水の凝縮によって低 温部を加熱する。

（2）水分によって，その物体の熱物性（熱㐾導度や比熱 など）の值が変化する.

（3）水の分子拡散によって，熱が直接移動する. などの影響が考えられるが，一度大気中に放出された水 分は,すなわち揮発ガス中においては, 固体中に存在す る場合ほど着火や燃焼に及ぼす影響を与えない.

(2)の現象については, 数人の研究者によって補正式が 提案されている. Fon ${ }^{301}$ らは，比熱については次なる式 にて水分による(1)の影響むすべて比熱の項で補正しよう としている.
$\mathrm{C}_{\mathrm{m}}=\mathrm{C}_{\mathrm{o}}+\left\{\Delta \mathrm{W}+0.01\left(\mathrm{~L}+\theta_{0}\right) \mathrm{M}\right\} / \theta_{\mathrm{F}}$
$\mathrm{C}_{0}$ : 乾燥状態の木片の比熱 $-0.34 \mathrm{cal} / \mathrm{g}^{\circ} \mathrm{C}$
$\mathrm{C}_{\mathrm{m}}$ : 水分を含んだ状態での比熱 $\left(\mathrm{cal} / \mathrm{g}^{\circ} \mathrm{C}\right)$
$\mathrm{M}:$ 乾物基準の水分 $(\%)$
$\Delta \mathrm{W}:$ 加水による熱: $16 \mathrm{cal} / \mathrm{g}$
$\mathrm{L}:$ 潜熱 $=520 \mathrm{cal} / \mathrm{g}$
$\theta_{\text {o }}$ : 初期状態から $100^{\circ} \mathrm{C}$ までの温度上昇 $\left({ }^{\circ} \mathrm{C}\right)$
$\theta_{\mathrm{F}}:$ 発火時の表面温度 $\left({ }^{\circ} \mathrm{C}\right)$

また，熱伝導率については，Maclean ${ }^{31)}$ によれ゙，

$\mathrm{K}_{\mathrm{m}}=10^{-4}\left\{\rho_{\mathrm{o}}(4.78+10.2 \mathrm{~m})+0.57\right\}$

$\mathrm{K}_{\mathrm{m}}$ : 水分を含んだ状態の木片の熱伝導率 $(\mathrm{cal} / \mathrm{cm}$ ・ $\sec \cdot{ }^{\circ} \mathrm{C}$

$\mathrm{m}: 0.01 \mathrm{M}$

$\rho_{\circ}:$ 乾燥状態の木片の密度 $\left(\mathrm{g} / \mathrm{cm}^{3}\right)$ なる実験式を示している。

$\mathrm{Simms}^{29)}$ はこれらの補正式を(6-10) 式に代入して, 水分を含んだ木片に対する着火現象を説明し, 実験值と 比較的よい一致を見いだしている.ての結果, 水分を含 んだ木片での発火時の表面温度は, 乾燥状態のそれとほ とんご変わることがないことを明らかにした。

しかし，一般的に水分を含んだ物質の着火ならびに然 焼に関しては，防火災面の研究者はさほど興味を示さ ず，実験を行なっても，たかだか $30 \%$ 水分程度までのも のにとどまっている.

したがって，水分 $60 \%$ 前後のいわゆる 固体廃棄物で は, しばしば現われる含水率付近の着火や燃焼現象の研 究は，非常に少ないのが現状である。

\section{6-4 セルロースの低温域での自然発火}

\section{(Self-Ignition)}

この低温域での自然発火は, 物体内に発生したわずか の熱が，断熱的な状態におかれたため，しだいに蓄積し 温度上䄯をきたし，そして遂に発火する現象である。

從来, 石炭やセルロイドなどについて古くから研究が 
なされていたが，セルロース物質の自然発火の研究は， あまり行なわれていない。

この現象についてあ秋田 ${ }^{31}$ の研究が著名である.セル ロース物質を $300^{\circ} \mathrm{C}$ 付近の低温で加熱し，热分解させる と, その内部で発热を呈することが認められているが, とれは, セルロースの270〜300 Cにおける分解反応は， 発熱反応であり, その生成物す 1 次反応生成物, 2 次反 応生成物があり，それらが複雑に分解や重合を行なって いると考えられている.

との発熱反応の発熱量は, 书よそ $30 \mathrm{cal} / \mathrm{g}$ 程度とされ ているが，乙れは，七ルロース物質があつ燃焼発熱量 （通常4200 4400 cal $/ \mathrm{g}$ ）に較べると非常に小さいもの である.

この低温域での自然発火の発火点の判定は，なかなか 困難であるが, 秋田らの実験によれば, 温度が䫓著な立 ちあがりを示す点を発火点としてみると，その物質の大 きさによって，かなり左右されるが木粉（見かけ密度 $\left.0.14 \mathrm{~g} / \mathrm{cm}^{3}\right)$ で $170 \sim 190^{\circ} \mathrm{C}$ と測定される. 乙れを温度分 布の変曲点を基準侤考ると $210^{\circ} \mathrm{C}$ 付近となる.

木炭などの無炎発火は $200^{\circ} \mathrm{C}$ 前後から生ずるといわれ ているととなどから推察すると，七ルロース物質の低温 域での自然発火の温度は 180 ～ $200^{\circ} \mathrm{C}$ であると考えられ る.む万ん，乙の様な温度で発火するためには，その物 質が外部之断熱条件下におかれていて, 蓄熱が可能な状 態でなければならず，しかも蓄熱には時間を要し，先の 秋田の実験でも, 加熱温度 $170 \sim 200^{\circ} \mathrm{C}$ で発火までに平均 300分を要している.

したがって，とのセルロース物質の低温域の発火現象 は, セルロース系固体廃䢂物の焼却処理には, 直接的に 関与する場合は少ないが，セルロース系の物質を堆積む
しくは理立する場合には，上記のような条件が整うと自 然発火することは, 充分認知しておく必要がある.

\section{$<$ 引用文献 $>$}

20) D. L. Simms, D. I. Lawson "Ignition of Wood by Radiation” Brit. J. App. Phys. Vol. 3 pp 288 (1952)

21）秋田一雄 “熱発火理論の方程式展望”「燃焼研究」 Vol. 9 pp 2 (1965)

22) C. H. Bamford, J. Crank, D. H. Malan, "The Combustion of Wood Part 1" Proc. Camb. Phil Soc. Vol. 42 pp 166 (1946)

23) D. L. Simms "Ignition of Cellulosic Materials by Radiation" Comb \& Flame, Vol. 4 No. 4 pp 293 (1960)

24) D. L. Simms "Damage to Cellulosic Materials thermal Radiation" Comb \& Flame, Vol. 6 No. 4 pp 303 (1962)

25) S. B. Martin, N. J. Alvares "Mechanisms of Ignition of Thermally Irradiated Cellulose" 13th Symposium (International) on Combustion pp 905 The Combustion Institute (1971)

26) W. D. Weatherford, D. M. Sheppard "Basic Studies of the Mechanism of Ignition of Cellulosic Materials" 10th Symposium (International) on Combustion pp 897 The Combustion Institute (1965)

27) W. H. Andersen "Theory of Surface Ignition with Application to Cellulose, Explosives and Propellants" Comb. Sci. Tech. Vol. 2 pp 213 (1970)

28) D. L. Simms, "On the Pilot Ignition of Wood by Radiation” Comb. \& Flame Vol. 7 No. 3 pp 253 (1963)

29) D. L. Simms, M. Law, "The Ignition of Wet and Dry Wood by Radiation" Comb. \& Flame, Vol. 11 pp 377 (1967)

30) W. L. Fons, J. Agr. Research Vol. 172 No. 3 pp 93 $\sim 121$ (1946)

31) J. D. Maclean "The Thermal Conductivity of Wood" Trans. Awer. Soc. Heat Vent Engrs. Vol. 47 pp 1184 (1941) 